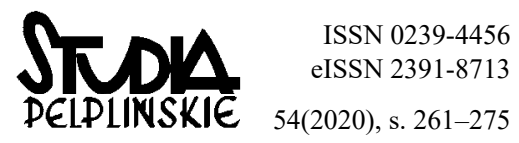

KS. WALDEMAR PRONDZINSKI

WSKSiM Toruń

w.prondzinski@onet.pl

ORCID: 0000-0001-7580-7982

\section{HOMILIA LITURGICZNA \\ WEDLUG KS. KAZIMIERZA BIESZKA \\ PIONIERA RUCHU LITURGICZNEGO W POLSCE}

DOI: http://dx.doi.org/10.12775/SPLP.2020.012

\section{Streszczenie}

Ks. Kazimierz Bieszk (1890-1946) to jeden z najbardziej znanych propagatorów odnowy liturgicznej w Polsce, szczególnie na Pomorzu. Z pasją i wiarą pochylał się nad formą i treścią zawartą w liturgii Kościoła, by w duchu Ruchu Liturgicznego dzielić się tym spojrzeniem głosząc homilie, pisząc artykuły na łamach czasopism: „Misterium Christi”, „Pielgrzyma”; oraz prowadząc wykłady w WSD w Pelplinie. Jego przekaz oparty był na: miłości do liturgii, rozumieniu pastoralnego jej charakteru oraz dogmatycznych podstaw głoszenia słowa. Ks. Bieszk był świadomy, jak ważną rolę w duszpasterstwie jako wychowaniu do świadomego, czynnego i owocnego udziału w liturgii, pełnią kazania, homilie oraz rekolekcje o tematyce liturgicznej. Uważał, że liturgia powinna być dla kaznodziei punktem wyjścia, jeśli ten chce prowadzić wiernych właśnie do liturgii. Efekt pracy liturgicznego wychowania, kompetencje ks. Bieszka, używane najnowsze metody oraz idee szkoły twórczej, wpłynęły m.in. na wykształcenie wielu żarliwych katechetów oraz prefektów szkół średnich diecezji chełmińskiej. W konsekwencji skutkiem odnowy życia liturgicznego była także odnowa kaznodziejstwa.

Słowa klucze: ks. Kazimierz Bieszk, Ruch Liturgiczny, homilia liturgiczna, odnowa liturgiczna 


\section{Liturgical Homily according to Kazimierz Bieszk \\ - a Pioneer of Polish Liturgical Movement}

\section{Summary}

Rev. Kazimierz Bieszk (1890-1946) is one of the most prominent promoters of liturgical renewal in Poland, especially in Pomerania. He looked with passion and faith at Church's liturgical forms and contents and then shared his ideas in sermons, scientific articles published in "Misterium Christi" and "Pielgrzym" as well as in the classes given at the Priestly Seminary in Pelplin. The pillars of Father Bieszk's activity were his love for the liturgy and understanding of its pastoral character and of the dogmatic basis of preaching of the Word of God. As a priest he was aware of the crucial role sermons, homilies and liturgically themed retreats have in the pastoral ministry whose goal is to form the faithful to participate in the liturgy consciously, actively and fruitfully. Moreover, the liturgy should be to for every preacher a point of reference if one wants to lead the people towards its better understanding. Rev. Kazimierz Bieszk's efforts of liturgical formation, his personal competence, the usage the most up-to-date methods and creativity allowed the Diocese of Chelmno to educate many passionate RE teachers and cathechists. Finally, the liturgical renewal also led to better preaching.

Keywords: Kazimierz Bieszk, liturgical movement, liturgical homily, liturgical renewal

Niewątpliwie wśród wybitnych teologów przedsoborowego środowiska pelplińskiego, na uwagę zasługuje ks. Kazimierz Bieszk ${ }^{1}$. Jego aktywność naukowa jako liturgisty i homilety, każe zaliczyć go do najbardziej znanych propagatorów odnowy liturgicznej w Polsce, a szczególnie na Pomorzu. Naukowcy, wywodzący się ze środowiska pelplińskiego, niejednokrotnie w swoich pracach podejmowali problematykę związaną z jego dorobkiem we wspomnianych dziedzinach.

Zob. H. Mross, Bieszk Kazimierz (1890-1946), homiletyk, liturgista, redaktor, w: Stownik Polskich Teologów Katolickich 1918-1981, red. L. Grzebień, Warszawa 1983, s. 108-111; S. Człapa, Kazimierz Bieszk, EK 2, kol. 553; A. Nadolny, Pelpliński Krą Historyczny, w: Dzieje Historiografii Pomorza Gdańskiego i Prus Wschodnich 1920-1939 (1944), red.: A. Tomczak, Torun 1991, s. $44-45$. 


\section{OSOBOWOŚĆ}

W ciepłych barwach osobę ks. Bieszka w swoim wspomnieniu nakreślił bp Zygfryd Kowalski. Pisał, iż swoją osobowoscią potrafił oddziaływać nie tylko na uczniów, kolegów oraz przyjaciół, ale nade wszystko na swoich przeciwników. Ks. Franciszek Manthey twierdził, że poprzez jego fascynującą osobowość wszyscy stawali się jego uczniami: starsi i młodsi, współbracia i koledzy, studenci i alumni ${ }^{2}$. Wśród uczniów, dla których był inspiratorem idei liturgicznej należy wymienić m.in.: wspomnianego tu Zygfryda Kowalskiego oraz Stefana Wincentego Frelichowskiego ${ }^{3}$. Opinie o nim i jego popularność wśród kleryków wyróżniały go wśród innych wykładowców. Miał w sobie wiele empatii, rozmawiając z człowiekiem potrafił wczuć się w jego położenie i psychikę . Źródłem tej postawy była niewątpliwie wiara. Kochał Boga, posiadał serce wrażliwe na dzieło Stwórcy, którego poznawał przez studium i własną obserwację przyrody ${ }^{5}$.

W swej pracy naukowej dotyczącej duchowieństwa diecezji pelplińskiej ks. Jan Walkusz przytacza jeszcze jedno, nacechowane emocjonalnie świadectwo o ks. Bieszku, zapisane przez jego przyjaciela, mianowicie wspomnianego już ks. Mantheya. Otóż podkreślał on, że jego szlachetna dusza potrafiła porwać każdego, z kim się spotykał, gdyż nie znał egoizmu, zniechęcenia, a nadto chętnie poświęcał swój czas dla drugich. Wspierał biednych, pomagał gimnazjalistom w zadaniach szkolnych, potrafił dodać otuchy zrozpaczonym oraz prowadzić zagubionych na drogę moralności. Alumni bardziej niż ojcu duchownemu powierzali mu swoje trudności ${ }^{6}$. Panowała o nim opinia, że każdy ksiądz, który przyjeżdżał do Pelplina, choć na chwilę chciał się spotkać z ks. Bieszkiem. Przyjeżdżali do niego także młodzi poeci, by prosić o recenzję swojej twórczości. Ks. Kazimierz Bieszk „dla każdego miał czas, dobre słowo, uśmiech, zachętę, książkę, pieniądz, papierosa lub kawałek chleba"?.

2 Zob. F. Manthey, Ks. Kazimierz Bieszk, w: J. Borzyszkowski, Pro Memoria, Stefan Bieszk (1895-1964), Gdańsk 2013, s. 122-124; H. Jastak, Dorobek homiletyczny Ks. Pratata Dr Kazimierza Bieszka, Pelplin, s. 16.

3 S. Człapa, Ks. dr Kazimierz Bieszk - Prekursor Odnowy Liturgii i Wychowawca, „Studia Pelplińskie”, 1984, t. XV, s. 78; R. Zadura, Btogostawiony ks. Stefan Frelichowski (1913-1945). Biografia, Toruń 2006, s. 103.

4 J. Walkusz, Duchowieństwo katolickie diecezji chetmińskiej w latach 1918-1939, Pelplin 1992, s. 132.

5 H. Jastak, dz. cyt., s. 17.

6 Zob. F. Manthey, Ks. Kazimierz Bieszk, w: J. Walkusz, Duchowieństwo katolickie diecezji chetmińskiej w latach 1918-1939, Pelplin 1992, s. 130; R. Zadura, dz. cyt., s. 92.

7 F. Manthey, Ks. Kazimierz Bieszk, w: J. Walkusz, Duchowieństwo katolickie diecezji chetmińskiej w latach 1918-1939, dz. cyt., s. 122, 130. 


\section{RYS HISTORYCZNY}

Środowisko naukowe Pelplina od zawsze miało świadomość nieprzeciętności dorobku naukowego ks. Bieszka. Wpływ na utrwalenie jego działalności miały prace podejmowane przez ks. Stanisława Człapę, późniejszego następcę wybitnego liturgisty. Ks. Człapa włożył wiele wysiłku w utrwalenie i popularyzację poglądów Ks. Bieszka, starając się by nie utraciły one swego wyrazu. Osoba tego pioniera nie została także pominięta w pracach ks. Anastazego Nadolnego, ks. Jana Walkusza oraz ks. Andrzeja Meggera ${ }^{8}$.

Autorzy w swoich pracach kreślą kontekst, w którym znalazła się myśl ks. Bieszka. Otóż reforma programu nauczania w seminarium następowała już w połowie lat dwudziestych, niemniej generalne zmiany, polegające na ujednoliceniu studiów w kraju rozpoczęły się w $1921 \mathrm{r}$. Wtedy to profesorowie pelplińskiej uczelni uczestniczyli w zjazdach Związku Zakładów Teologicznych w Polsce. Bieszk podjął pracę w seminarium 1 października 1923 roku. Jednak wykłady z liturgiki i homiletyki prowadził w latach $1935-1939^{9}$. O ile w diecezji wspierana była inicjatywa działalności w dziedzinie szerzenia zamiłowania do historii, której propagatorem był ks. Franciszek Sawicki, o tyle nie można powiedzieć tego o pracy na rzecz krzewienia liturgii wśród młodzieży seminaryjnej. $Z$ badań ks. Jana Walkusza dowiadujemy się, że działalność liturgisty spotkała się z niezrozumieniem i dezaprobatą profesorów i biskupa Okoniewskiego.

Ks. Bieszk rozpoczął kształcenie alumnów od założenia „kółka liturgicznego”, którego spotkania odbywały się w mieszkaniu profesora. Seminarzyści zapoznawali się tam z najnowszymi trendami, ekskluzywnością głoszonych na Zachodzie haseł o liturgii - swego rodzaju uwspółcześnienia życia liturgicznego. Pochylano się nad formą i treścią zawartą w liturgii Kościoła w duchu Ruchu Liturgicznego ${ }^{10}$. Poznawano sens liturgii mszalnej oraz przygotowywano homilie ${ }^{11}$. Ks. Człapa pisał, że Bieszk jako jeden z pierwszych przeniósł na grunt Polski działalność: Prospera Guerangera, od którego odziedziczył miłość do liturgii, Ildefonsa Herwegena, który nadawał liturgii dogmatyczne podstawy, natomiast od Piusa Parscha zaczerpnął pastoralny charakter liturgii ${ }^{12}$. W ten sposób członkowie koła przeżywali

Zob. A. Megger, Studia Pelplińskie w stużbie Liturgii, „Studia Pelplińskie”, t. 50(2017), s. 80.

9 Zob. W. Szulist, Przeszłość obecnych obszarów diecezji pelplińskiej 1929-1939, Pelplin 2009, t. III, s. 73; J. Walkusz, dz. cyt., s. 61. Zob. W. Wielgoszewski, Pedagog, który zblizat do Boga. Duchowni diecezji chetmińskiej (9A), „Niedziela”, 23(2007), s. 2.

10 Zob. S. Człapa, Ks. Kazimierz Bieszkjak Liturgista, „Studia Pelplińskie”, 1978, s. 311; J. Walkusz, dz. cyt., s. 119.

11 Zob. S. Człapa, Ks. dr Kazimierz Bieszk - Prekursor Odnowy Liturgii i Wychowawca, dz. cyt., s. 78.

12 Zob. tamże, s. 84-86. 
liturgię. Po raz pierwszy w diecezji msze św. twarzą do ludu odprawiał ks. Bieszk już w 1935r. ${ }^{13}$ Propagatorów odnowy liturgicznej określano lekceważąco „bractwem katakumbowym", natomiast ich aspiracje ściśle ograniczano.

Przełom stanowiły lata 1936-1937, to w tym czasie poglądy ks. Bieszka, publikowane na łamach czasopisma „Misterium Christi” doczekały się powszechnego uznania w Polsce. Tym samym, w krótkim czasie prowadzone przez niego kółko otrzymało statut samodzielnego seminarium liturgicznego ${ }^{14}$. Wykłady prowadził z niebywałym entuzjazmem, unikał systematyzacji, podążał za tym, co nowe ${ }^{15}$. Należy zaznaczyć, że nie miały one charakteru amatorskiego. Jego doskonała orientacja w ówczesnej literaturze liturgicznej dała chrystocentryczną podbudowę duszpasterstwu polskiemu przed II wojną światową. Stosowana w nich metoda pracy miała doniosłe znaczenie. Służyła swymi osiągnięciami w kształtowaniu także kleru poza diecezją ${ }^{16}$. Krzewiona z przekonaniem odnowa liturgii skutkowała faktem, iż właśnie wśród jego wychowanków posoborowa odnowa uzyskała najwięcej zrozumienia ${ }^{17}$.

\section{HOMILIA}

Zagadnienia soborowej Konstytucji o Liturgii uporządkowane są według następującej kolejności: teologia, historia, duchowość, aspekt duszpasterski oraz prawny $(\mathrm{KL} 16)^{18}$. Ks. Bieszk, idąc za Piusem Paschem, miał swój współudział w kształtowaniu trzech spośród wyżej wymienionych kwestii. Mianowicie: historycznej, której zastosowanie znajdował dla wyjaśniania istniejących form kultu, dalej teologicznej ${ }^{19}$, która służyła mu jako zgłębienie i wyjaśnienie ceremonii i obrzędów oraz duszpasterskiej. Niemniej ks. Człapa, zauważa, że najwięcej w jego pracach uwzględniony zostaje właśnie ostatni pastoralny aspekt liturgii ${ }^{20}$. Ks. Bieszk był świadomy, jak ważną rolę w duszpasterstwie jako wychowaniu do świadomego,

Zob. J. Walkusz, dz. cyt., s. 119; W. Szulist, dz. cyt., s. 73.

14 Zob. J. Walkusz, dz. cyt., s. 120; H. Jastak, dz. cyt., s. 21, 89. Zob. J. Walkusz, dz. cyt., s. 388; S. Człapa, Ks. dr Kazimierz Bieszk - Prekursor Odnowy Liturgii i Wychowawca, dz. cyt., s. 77.

15 Zob. A. Liedtke, Straty teologiczne nauki polskiej podczas wojny, „Ateneum Kapłańskie”, t. 47(1947), s. 323.

16 Zob. J. Walkusz, Duchowieństwo katolickie diecezji chetmińskiej w latach 1918-1939, Pelplin 1992, s. 121; H. Jastak, dz. cyt., s. 15.

17 Zob. tamże, s. 41; S. Człapa, Ks. dr Kazimierz Bieszk-Prekursor Odnowy Liturgii i Wychowawca, dz. cyt., s. 79; A. Megger, dz. cyt., s. 80.

18 Zob. B. Kosecki, Znajomość Historii Liturgii Warunkiem Skutecznej Odnowy Liturgicznej, „Studia Pelplińskie" t. 11(1980), s. 187; A. Megger, dz. cyt., s. 73.

19 Zob. K. Bieszk, Liturgia jako źródto kazań, Kielce 1935, s. 49-50; K. Bieszk, Liturgia, „Homiletyka Duszpasterska", 1935, s. 270-271.

20 Zob. S. Człapa, Ks. dr Kazimierz jako Liturgista, dz. cyt., s. 330. 
czynnego i owocnego udziału w liturgii, pełnią kazania, homilie oraz rekolekcje o tematyce liturgicznej (IOe 19) ${ }^{21}$. Lider podkreślał, iż częstotliwość głoszenia tychże kazań winna być warunkowana potrzebą oraz dostrojeniem do danego okresu liturgicznego. Zaznaczał, jak ważne jest zachowanie pewnej systematyczności cyklu powtarzającego się na przestrzeni lat ${ }^{22}$. Twierdził, że liturgia powinna być dla kaznodziei punktem wyjścia, jeśli ten chce prowadzić wiernych właśnie do liturgii. Inspiracją dla tej myśli były dla ks. Bieszka w pierwszej kolejności Motu Proprio Piusa X z 22 października 1903 r. Papież stwierdza tam, iż ważnym czynnikiem w rozwoju wiary jest świętość i powaga świątyni, w której wierni biorą czynny udział w liturgii jako źródle. Następnie Konstytucja Apostolska „Divini Cultus” z 20 grudnia 1928r., w której Pius XI przypomniał o liturgicznej mocy uświadomienia religijnego, czyli liturgii jako źródle wiedzy religijnej ${ }^{23}$.

Dorobek homiletyczny ks. Bieszka można podzielić na trzy grupy. Pierwsza to Rozważania, które publikował na łamach „Misterium Christi”. Kolejna: Kazania zamieszczone w dodatku do pisma „Pielgrzym”, czy w kalendarzu parafialnym św. Józefa w Tczewie oraz kazanie w języku niemieckim pt. In Erwartung. Ostatnia to Szkice, które ukazały się w piśmie pt. „Homiletyka Duszpasterska” wydawanym w Katowicach ${ }^{24}$.

O szerokim zastosowaniu tematu liturgii w homilii poświadczył publikacją pt. Liturgia źródłem kazań, wydaną w Kielcach w 1935 roku. Ks. Walkusz zauważa, że w okresie międzywojennym na terenie diecezji chełmińskiej prawdopodobnie jedynie ks. Bieszk zajął się teorią głoszenia Słowa Bożego ${ }^{25}$.

\section{METODA}

Ks. Bieszk zauważył, iż ogromny wysiłek głoszących włożony w racjonalizację oraz systematyzację treść, przynosił minimalny wynik. Analizując potrzeby słuchaczy wysnuł wniosek, że odbiorca jest prostym człowiekiem, który może nauczyć się wiary przez praktykę, a nie abstrakcję. Dlatego też widział w liturgii popularyzatorkę teologii. Człowiek przez liturgię może nauczyć się katechizmu „na kolanach”26. Z drugiej zaś strony dociekania Bieszka pozwoliły mu opiniować

${ }^{21}$ Zob. H. Jastak, dz. cyt., s. 18, 25, 86-87; S. Człapa, Ks. dr Kazimierz Bieszk-Prekursor Odnowy Liturgii i Wychowawca, dz. cyt., s. 77.

22 Zob. K. Bieszk, Liturgia jako źródto kazań, dz. cyt., s. 36, 51.

${ }^{23}$ K. Bieszk, Liturgia jako źródło kazań, dz. cyt., s. 7, 48-49; H. Jastak, dz. cyt., s. 106; S. Człapa, Ks. Kazimierz Bieszk jako Liturgista, dz. cyt., s. 314.

24 Zob. H. Jastak, dz. cyt., s. 24.

25 Zob. J. Walkusz, dz. cyt., s. 376.

${ }^{26}$ K. Bieszk, Liturgia jako źródto kazań, dz. cyt., s. 8; Benedykt XVI, Adhortacja apostolska ,Sacramentum Caritatis”, Rzym 2007, 15; tenże, Adhortacja apostolska ,Verbum Domini”, Rzym $2010,52-55$. 
o kiepskiej egzegezie ówczesnych kaznodziejów, która nie zadowalała inteligencji. Ludzie wykształceni nie domagali się powtarzania utartych haseł, na przemian, bardziej lub mniej ekspresywnie, gdyż to wywoływało jedynie ironiczne zniechęcenie słuchacza, zanim jeszcze usłyszał, co kaznodzieja chciał powiedzieć (Zob. EG 135 $)^{27}$.

Mimo, iż według ks. Bieszka metoda głoszenia kazania liturgicznego powinna pozostać polem indywidualnego opracowania homilii ${ }^{28}$, ks. Bieszk podał pewne elementy stałe. Podkreślał przy tym, iż kaznodzieja powinien wspierać się tekstem wcześniej przygotowanym na medytacji Słowa ${ }^{29}$. Natomiast wierni winni w czasie takiej homilii wspierać się mszalikiem, by móc śledzić tok myśli. Nadto zauważył, że nie może być w takiej homilii miejsca na alegorię oraz thumaczenia mistyczne, jako że są one spuścizną średniowieczną i mogą zrażać słuchacza, który myśli rzeczowo. W takiej homilii nie miało być również miejsca na „,przydługie” wywody dogmatyczne oraz ascetyczne, które obciążają słuchacza. Przy tej okazji liturgista podjął się krytyki m.in. kazań ks. Mikołaja Gihra ${ }^{30}$.

Według ks. Bieszka kaznodzieja winien zachować konstruktywną jedność homilii. Główna myśl przekazu nie powinna być zakryta nieistotnymi szczegółami, które jedynie przemęczają odbiorcę ${ }^{31}$. Nie chodzi tu o pominięcie urozmaicenia homilii, lecz o podkreślenie, że dokona się ono samoczynnie, bo jest wynikiem braku jednostajności samej liturgii, jako przedmiotu przepowiadania ${ }^{32}$. Umiejętne ukazanie przemyśleń, polegające na błyskotliwym przechodzeniu między tematami, przy jednoczesnym logicznym ujęciu całości wypowiedzi wystarczyć miało, by odbiorca uważnie wysłuchał mowy ${ }^{33}$.

\section{FORMA}

Ks. Bieszk, idąc za wskazaniem Jacquesa-Bénigne'a Bossueta, starał się w taki sposób ując słuchacza, by ten odnosił wrażenie, że mówca rozmawia jedynie z nim ${ }^{34}$. Natomiast sama forma wypowiedzi i przekaz posiadać miał charakter

27 Zob. K. Bieszk, Co sądza świeccy o kazaniu, „Miesięcznik Diecezji Chełmińskiej”, 1933, s. 522; H. Jastak, dz. cyt., s. 96, 100.

28 Zob. K. Bieszk, Liturgia jako źródto kazań, dz. cyt., s. 50; H. Jastak, dz. cyt., s. 92.

29 Zob. K. Bieszk, Liturgia jako źródto kazań, dz. cyt., s. 50; H. Jastak, dz. cyt., s. 81, 88, 93; Cz. Krakowiak, Eucharystia w parafii. Teologia i praktyka pastoralna, Lublin 2014, s. 40.

30 Zob. K. Bieszk, Liturgia jako źródło kazań, dz. cyt., s. 50.

31 Zob. tamże, s. 20, 51; H. Jastak, dz. cyt., s. 71; H. Sławiński, Tematyczne Programowanie Przepowiadania Homilijnego, „Roczniki Teologiczne”, t. 62(2015), s. 78-79, 86.

32 Zob. K. Bieszk, Liturgia jako źródto kazań, dz. cyt., s. 51

33 Zob. H. Jastak, dz. cyt., s. 18; H. Sławiński, Tematyczne Programowanie Przepowiadania Homilijnego, dz. cyt., s. 87.

34 Zob. H. Jastak, dz. cyt., s. 23. 
nacechowany optymizmem, co wynikało z radosnego przekazu Ewangelii, a jednocześnie było zaprzeczeniem wobec trudności i pesymizmu zmagania się z życiem codziennym ${ }^{35}$. Przynależąc do grupy homiletów, którym patronował św. Bonawentura, Bieszk wychodził z założenia, że głównie należy oddziaływać afektem wobec słuchacza, stwarzając mu sytuację pozwalającą ,przeżyć”, a dopiero w drugiej kolejności ,przyjąć” treść wiary rozumowo. Wywołanie silnych uczuć u odbiorcy miało dać lepszą możliwość przyswojenia przekazanej prawdy ${ }^{36}$. Tak więc dla ks. Bieszka „liturgia jest żyjącym dogmatem”, który domaga się stałej aktualizacji do danej sytuacji człowieka oraz różnorodności percepcji słuchaczy ${ }^{38}$. Akt liturgiczny Kościoła jest zatem momentem nauczania łączącym w sobie aspekt psychologiczny oraz praktyczny. Powyższe ujęcie uważał Bieszk za dekretowane przez Kościół jako jedyną i autentyczną formę $e^{39}$.

\section{TREŚĆ}

W pierwszej kolejności Bieszk zwracał uwagę na wyartykułowanie postulatów kazania oraz wsłuchanie się w opinie słuchaczy na temat głoszonych przez siebie kazań $^{40}$. Jeśli chodzi o cel kazań liturgicznych, czy jak rozróżnia ks. Bieszk - cel kazań katechizmowych o liturgii, doszukiwał się go w etymologii słowa „liturgia”. Twierdził, iż nie może ona zaistnieć bez udziału wiernych, gdyż jest aktem czci Mistycznego Ciała Syna wobec Ojca, co winno stanowić o celu kazania. Święty akt zatem może się dokonać przez czynny udział, wyrażony w ,przejęciu na wskroś ${ }^{41}$ " uczestnictwem w Dramacie. Jest to swego rodzaju objaw kultury religijnej. Ks. Bieszk odwołując się do myśli ks. Andrzeja Wronki podkreślił, że akt ten jest możliwy jedynie, kiedy jest uświadomiony, zatem wskazuje na potrzebę „nawrócenia do liturgii”42, polegającą na objaśnianiu jej znaczenia, tekstów oraz symboli. Do czego wystarczyć mają: „umiejętność korzystania z języka współczesnego, zwięzły styl, brak oklepanych zwrotów, krótkie i zasadnicze zdania oraz odniesienie do współczesności" "43.

35 Zob. tamże, s. 97-98.

36 Zob. tamże, s. 24, 33, 93-94.

37 K. Bieszk, Liturgia jako źródło kazań, dz. cyt., s. 9

38 Zob. H. Jastak, dz. cyt., s. 95, 98.

39 Zob. S. Człapa, Ks. Kazimierz Bieszk Jako Liturgista, dz. cyt., s. 321.

40 Zob. H. Jastak, dz. cyt., s. 94-95.

${ }^{41}$ Zob. K. Bieszk, Liturgia jako źródło kazań, dz. cyt., s. 9.

42 Zob. A. Wronka, Liturgia na ambonie. Zasady i wskazówki, Poznań 1933, s. 13; K. Bieszk, Liturgia jako źródło kazań, dz. cyt., s. 10.

43 H. Jastak, dz. cyt., s. 99-100, 102. 
Dla ks. Bieszka liturgia jako służba Boża - cultus divinus, jako życie Boskie w szeregu źródeł, tj.: Pisma św., Tradycji, Teologii usytuowana jest nadrzędnie. Argumentował to tym, iż: liturgia swe teksty czerpie z Biblii, wobec Tradycji jest ona żywym jej świadkiem, odnośnie zaś do teologii - uczy poprzez wdrażanie $\mathrm{w}$ życie chrześcijańskie prawd wiary zawartych w tejże nauce ${ }^{44}$. Ks. Bieszk podkreślał, że celem nie jest sama nauka oraz przestrzeganie moralności. Choć nie pomniejszał ich roli, gdyż dostrzegał wartość wysiłku ludzkiego, widział w nich jedynie drogę do celu, którym samym w sobie jest urzeczywistnianie, uobecnianie i kontynuowanie zbawczego dzieła Chrystusa, wobec którego liturgia staje się ośrodkiem oraz duszą (Mt 28, 19-20; J 10,10) ${ }^{45}$, organicznym życiem ${ }^{46}$.

Bieszk twierdził, że Jezus nie zbawił świata nauką, ale swoją śmiercią. Zatem „liturgia nie jest nauką, a życiem" " ${ }^{47}$. Zauważał, że początkiem chrześcijaństwa i Kościoła nie są słowa Jezusa o prawie moralnym, czy systemie teologicznym, ale jest nim łaska - żywa siła Boża, wyrażona przez Jego byt w: zjednoczeniu z człowiekiem, działaniu dla człowieka, cierpieniu dla człowieka, krzyżu i Zmartwychwstaniu ${ }^{48}$. Tak więc wszelka nauka płynąca z ołtarza Słowa powinna wzniecać, rozbudzać, „doprowadzać do rozkwitu i do ukoronowania Liturgii w wieczności" ${ }^{49}$ jako tej, która tu, w doczesności ,jest organem udzielania łaski" ${ }^{50}$ (zob. KL 7). Innymi słowy, pierwszym zadaniem kaznodziei jest przygotować słuchacza na przyjęcie łaski (por. IOe 55) ${ }^{51}$. Człowiek, uczestnicząc w liturgii, dostępuje odkupienia poprzez żywą obecność Chrystusa jako Głowy wobec swego Ciała, czyli Kościoła. W tym układzie pierwszorzędną rolę przed czynem ludzkim zajmuje urząd kapłański, który jest drogą działania Bożego. Ta łączność, polegająca na „wszczepieniu” w życie Chrystusa pozwala doświadczyć człowiekowi pełni życia, pełni życia Boga. Ks. Bieszk, odwołując się do myśli: Casela, van Oosta, Żukow-

${ }_{44}$ Zob. K. Bieszk, Liturgia jako źródło kazań, dz. cyt., s. 3; S. Człapa, Ks. Kazimierz Bieszk Jako Liturgista, dz. cyt., s. 342; H. Sławiński, Tematyczne Programowanie Przepowiadania Homilijnego, dz. cyt., s. 80 .

45 Zob. K. Bieszk, Liturgia jako źródło kazań, dz. cyt., s. 3; W. Broński, Homilia w dokumentach Kościoła współczesnego, „Studia Homiletyczne Katedry Homiletyki KUL”, t.1(1999), s. 141.

${ }^{46}$ Zob. K. Bieszk, Liturgia jako źródło kazań, dz. cyt., s. 7; W. Broński, Homilia w nauczaniu Kościoła wspótczesnego, ,, Studia Teologiczno-Filozoficzne Diecezji Rzeszowskiej”, t. 5(1998), s. 180.

47 K. Bieszk, Liturgia jako źródło kazań, dz. cyt., s. 4.

48 Zob. tamże, s. 4; P. Marini, Liturgia i Piękno Nobilis Pulchritudo, Pelplin 2017, s. 64.

49 K. Bieszk, Liturgia jako źródto kazań, dz. cyt., s. 3.

50 Tamże, s. 4; P. Marini, dz. cyt., s. 65; K. Panuś, Sztuka Głoszenia Kazań, Kraków 2008, s. 15.

51 K. Bieszk, Liturgia jako źródło kazań, dz. cyt., s. 8; H. Jastak, dz. cyt., s. 99; H. Sławiński, Znaczenie, geneza i struktura Dyrektorium Homiletycznego, „Polonia Sacra”, 19, 2015, nr 3, s. 167-169; A. Rutkowski, Liturgia zanurzeniem w Boża obecność, „Studia Pelplińskie”, t. 36(2005), s. 302-303, 305-306. 
skiego, Stonnera, Parscha, Webera, czy Ballea, położył wyraźny akcent w swoim nauczaniu na podkreślenie, iż „Msza św. jest ofiarą całego Kościoła oraz ucztą, ${ }^{2} 2$.

Swoją uwagę poświęcił także kazaniom liturgicznym o Roku Kościelnym. Przywoływał idee głoszone przez: Strickera, wspomnianego już Casela oraz Boppa, gdzie podkreślał, iż układ roku nie jest wytworem nauki, tak więc nie powstał jako schemat, a jako twór żywego wzrostu Kościoła ${ }^{53}$. Jego wskazówki obejmowały także kazania dotyczące: sakramentów ${ }^{54}$ i sakramentalió $w^{55}$.

Akcent chrystologiczny, czyli wyartykułowanie prawdy o Jezusie Chrystusie, Jedynym i Najwyższym Arcykapłanie i Pośredniku oraz Kościele jako Corpus Christi Mysticum, było dowodem, iż Bieszk znał podstawy teologiczne głoszone przez propagatorów odnowy ruchu liturgicznego ${ }^{56}$. Ks. Człapa podkreślił, że była to teologia na ów czas nowoczesna, gdyż w duchu Drugiego Soboru Watykańskiego ${ }^{57}$.

Potrzebę i znaczenie głoszenia kazań o tematyce liturgicznej, jako pierwszego źródła przepowiadania, Lider widział również w tym, iż liturgia powstawała, gdy mówiąc obrazowo „ziemia ciepła była jeszcze od krwi Jezusa" ${ }^{\text {"28 }}$. Bogactwo swej myśli i treści czerpie ona także z tego co było przed nią. Zaznaczał, że jej teologiczny charakter dotyczący zjednoczenia człowieka z Bogiem pozwala przeżyć podstawy wiary wyrażone $\mathrm{w}$ treści kerygmatu ${ }^{59}$. Gdzie na pierwsze miejsce wysuwa się wielkość i majestat Boga w Trójcy - Stwórcy, dalej prawda o Odkupieniu przez Syna Bożego - Pośrednika ${ }^{60}$, czy kwestia darowanego synostwa

${ }_{52}$ Zob. K. Bieszk, Kazania o Eucharystii, „Przegląd Homiletyczny”, t. 13(1935), s. 314-317; tenże, Liturgia jako źródto kazań, dz. cyt., s. 11-12, 18-24; S. Człapa, Ks. dr Kazimierz BieszkPrekursor Odnowy Liturgii i Wychowawca, dz. cyt., s. 76; H. Jastak, dz. cyt., s. 61-66, 106-108.

53 Zob. K. Bieszk, Liturgia jako źródło kazań, dz. cyt., s. 26-36; H. Jastak, dz. cyt., s. 79-80, $108-110$.

${ }_{54}$ Zob. K. Bieszk, Liturgia jako źródło kazań, dz. cyt., s. 39-43; H. Jastak, dz. cyt., s. 110-116.

${ }_{55}$ K. Bieszk, Liturgia jako źródto kazań, dz. cyt., s. 43-46; H. Jastak, dz. cyt., s. 54-61, 105, 116-117.

56 Zob. S. Człapa, Ks. dr Kazimierz Bieszk - Prekursor Odnowy Liturgii i Wychowawca, dz. cyt., s. 76; W. Broński, Homilia w dokumentach Kościoła współczesnego, dz. cyt., s. 137, 141-142; S. Dyk, Homilia - droga do żywego poznania Misterium Chrystusa, Kielce 2016, s. 31-32; A.M. Sicari, Eucharystia - Ofiara Chrystusa, Kościoła i ludzkości, w: Eucharystia, red. S. Stencel, Poznań 1986, s. 285-294; F. Blachnicki, Konieczność odnowy liturgii na tle jej tradycyjnej koncepcji, w: Wprowadzenie do liturgii, red. F. Blachnicki, W. Schenk, R. Zielasko, Poznań 1967, s. 29-32.

57 Zob. K. Bieszk, Ofiara Nowego Przymierza, Pelplin 1937, s. 4-5; S. Człapa, Ks. dr Kazimierz Bieszk-Prekursor Odnowy Liturgii i Wychowawca, dz. cyt., s. 76.

${ }_{58}$ Zob. K. Bieszk, Liturgia jako źródło kazań, dz. cyt., s. 6; S. Człapa, Ks. Kazimierz Bieszk jako Liturgista, dz. cyt., s. 348.

59 W latach trzydziestych XX w. zainicjowano kerygmatyczny ruch odnowy kaznodziejstwa. Zob. W. Przyczyna, Z zagadnień wspótczesnej homiletyki, Kraków 1993, s. 62-67.

${ }^{60}$ Zob. K. Bieszk, Liturgia jako źródto kazań, dz. cyt., s. 7. 
Bożego $^{61}$, następnie Osoba Ducha Świętego ${ }^{62}$, oraz wdrażanie do współżycia w Kościele jako społeczności liturgicznej, w jej wymiarze parafialnym ${ }^{63}$, gdzie uwzględnione zostało również powszechne kapłaństwo wiernych ${ }^{64}$. Mimo, iż Liturgista stosował teź świadectwo, czyli dzielenie się własnym przeżyciem, jako formą przemawiania ${ }^{65}$, twierdził, że kazania o liturgii chronią ją przed zniekształceniem. Nie pozwalają na subiektywny charakter liturgii, ani na infantylność w niej. Chronią ją przed kupiecko-żebraczą postawą wiernych, czy feminizmem oraz ujednolicają liturgię dla całego Kościoła. Przypominają, że w liturgii wierny samorzutnie oddaje jaźń Bogu, jednocześnie przyjmując Boże działanie ${ }^{66}$. Czerpiąc z Casela, ks. Bieszk przypominał, że zrozumienie liturgii pozwala zaakceptować prawdę o tym, że Zbawienie, choć historycznie minęło, mistycznie dokonuje się stale w czasie trwania liturgii ${ }^{67}$. W ten sposób przestaje być ona jedynie schematem, a staje się życiem. Jak zauważał ks. Bieszk, wymienione wyżej problemy wśród kościołów partykularnych pojawiały się tam, gdzie nie głoszono kazań o tematyce liturgicznej ${ }^{68}$. Wierni nie rozumiejąc liturgii popadali wobec niej w „,bezmyślność, tępotę i zniechęcenie"69. Niemniej samo głoszenie tychże treści miało dać korzyść także kaznodziei, gdyż ten czerpiąc z liturgii wypowiadane słowa uchronić miał się przed narzucaniem własnej indywidualności religijnej. W ten sposób homilia nie była moralizatorstwem, ani przeoczeniem wartości działań człowieka, ani jedynie mówieniem o miłości, ani wzbudzaniem lęku przed piekłemº ${ }^{70}$.

Ks. Bieszk nie umniejszał wartości modlitwy osobistej, jednak podkreślał, że liturgia chroni od skrajności tworzenia własnych obrazów Boga. Zatem zadaniem modlącego nie jest szukanie w modlitwie ulgi oraz drogi do czynienia postępów, a oddanie chwały Bogu. W ten sposób zaznaczał, że miłość do Boga nie może przeradzać się w brak dystansu i czci do Stwórcy. Tego typu podstawy, wykształcone szczególnie wśród młodzieży, miały pozwolić uniknąć jej lęku oraz skrupulanctwa religijnego ${ }^{71}$.

Kolejna kwestia poruszana przez ks. Bieszka dotyczyła ukazania homilii jako części integralnej, ukonstytuowanej w liturgii, jednak jej podporządkowanej. Dla

\footnotetext{
Zob. tamże, s. 10; H. Jastak, dz. cyt., s. 25.

Zob. K. Bieszk, Liturgia jako źródło kazań, dz. cyt., s. 7.

Zob. tamże, s. 10.

${ }^{64}$ Zob. K. Bieszk, Liturgia jako źródto kazań, dz. cyt., s. 10.

65 Zob. H. Jastak, dz. cyt., s. 34, 92.

${ }^{66}$ Zob. K. Bieszk, Liturgia jako źródło kazań, dz. cyt., s. 7. Por. D. Brzeziński, Teologiczne rozumienie liturgii. W 50 rocznica ogłoszenia encykliki Piusa XII „,Mediator Dei”, „,Miesięcznik Pasterski Płocki" 82(1997), s. 10; A. Rutkowski, dz. cyt., s. 299.

67 Zob. K. Bieszk, Liturgia jako źródło kazań, dz. cyt., s. 23.

68 Zob. tamże, s. 7.

69 Tamże, s. 50.

70 Zob. K. Bieszk, Liturgia jako źródło kazań, dz. cyt., s. 51; H. Jastak, dz. cyt., s. 97-98, 102-105.

71 Zob. tamże s. 26.
} 
ks. Bieszka jest ona jeszcze tylko dziełem jedynie ludzkim (por. DH4) ${ }^{72}$. Głoszący w pierwszej kolejności powinien wyttumaczyć to, co dzieje się w liturgii, by wierni mogli w niej właściwie uczestniczyć. Pionier zaznaczył, że Homilia nie jest zastąpieniem liturgii, a jedynie wprowadzeniem w nią. Dlatego głoszący nie powinien samoistnie stawiać homilii jako odrębnego tworu obok liturgii, a nawet pozostawiać pozoru, że jest ona od niej istotniejsza ${ }^{73}$. Ks. Bieszk krytycznie oceniał kaznodziejów, którzy uprawiali swe dzieło np. dotyczące idei danego święta, dla samego tylko kaznodziejstwa, ignorując przy tym treść bogactwa modlitewnego poprzedzającą głoszenie, które w tajemnice liturgii dnia wprowadzało ${ }^{74}$. Pomijanie tychże skarbów było dla ks. Bieszka swego rodzaju raną, jaką zadawali kaznodziejstwu głoszący. Niemniej oceniając sytuację sobie obecną, pisał, że zauważał pewien powrót, ku pierwotnemu porządkowi, którego rzecznikiem de facto stał się Pius X.

Należy jeszcze zauważyć, że w myśli ks. Bieszka istnieje pewnego rodzaju awersja do postrzegania ambony jako ołtarza słowa. Dla niego liczy się jedynie ołtarz eucharystyczny. Uprzedzenie wynikało z ostrożnego podejścia do Luteran, którzy kładli duży nacisk na głoszone słowo - sola scriptura ${ }^{75}$. Ks. Bieszk argumentował, że pierwotnie homilia „opierała się o ołtarz”, gdyż właśnie za nim przemawiał biskup z katedry. Następnie ambona (gr. pulpit, katedra, podwyższenie) została ustawiona przy balaskach, co podkreślić miało symbolikę Słowa Bożego jako pomostu między ołtarzem, a wiernymi ${ }^{76}$. Ks. Bieszk krytycznie wypowiadał się o ustawieniu ambony w środku nawy. Cytując ks. Franciszka Hettingera akcentował wartość przebudzenia, które dokonało się w XIX w. wobec homilii jako tej, która powinna mieć styczność z ołtarzem, czyli z liturgią ${ }^{77}$.

72 Zob. K. Bieszk, Liturgia jako źródło kazań, dz. cyt., s. 5; W. Broński, Homilia w nauczaniu Kościoła współczesnego, dz. cyt., s. 181-182, 184.

73 Zob. K. Bieszk, Liturgia jako źródto kazań, dz. cyt., s. 5, 21; H. Sławiński, Znaczenie, geneza i struktura Dyrektorium Homiletycznego, dz. cyt., s. 156; B. Nadolski, Liturgika. Eucharystia, Poznań 2011 t. 4, s. 210-211; Konferencja Episkopatu Polski, Wskazania Konferencji Episkopatu Polski dotyczace homilii mszalnej, Lublin 2017, s. 3-4.

74 Zob. K. Bieszk, Liturgia jako źródło kazań, dz. cyt., s. 6; M. Zachara, Msza Święta, Warszawa 2014, s. 134.

75 Zob. A.M. Sicari, Życie duchowe chrześcijanina, s. 342.

76 Por. D. Brzeziński, Uksztaltowanie $i$ wyposażenie wnętrza kościoła w odnowionym rycie rzymskim: aspekt liturgiczno-prawny, „Studia Płockie”, t. 29(2001), s. 93-94.

77 Zob. K. Bieszk, Liturgia jako źródło kazań, dz. cyt., s. 5. 


\section{ZAKOŃCZENIE}

Każda odnowa liturgii niesie z sobą ryzyko odejścia od Tradycji. Jeśli jej twórcy pragną jednak spełnić swoje zadanie wybiegając naprzód, winni zachować ciągłość. Delikatność obejścia winna dotyczyć tego co stanowi pierwiastek Boży w liturgii, gdyż jedynie pierwiastek ludzki może ulec zmianie w zależności od czasu i okoliczności ${ }^{78}$. Ważne, aby poznając gust, zmysł i ducha liturgii, uszanować i przekazać to co stałe, niezmienne, transcendentne, wspólne wszystkim liturgiom ${ }^{79}$. Współcześnie, dzięki odnowie liturgii jasnym jest, że istotą chrześcijaństwa jest wyrażana wiara, pobożność, postawa człowieka wobec Boga i do drugiego człowieka, oraz świata. Dla ks. Bieszka praktykowanie tychże wskazań stanowiło zwyczajną praktykę życia ${ }^{80}$. Ewangelia - jak wspominał ks. Liedtke - w pierwszej kolejności miała zastosowanie w życiu Lidera, a dopiero potem stawała się przedmiotem tłumaczenia wiernym. Unikanie systematyzacji oraz nieustanne poszukiwanie nowych dróg czynił Bieszk celem zbliżenia człowieka do Chrystusa. Gdzie głównym principium jego działalności było właśnie umiłowanie liturgii ${ }^{81}$. Efekt pracy liturgicznego wychowania, kompetencje ks. Bieszka, używane najnowsze metody oraz idee szkoły twórczej, wpłynęły m.in. na wykształcenie wielu żarliwych katechetów oraz prefektów szkół średnich diecezji chełmińskiej ${ }^{82}$. Jego bogate, twórcze, owocne życie, szlachetne cechy charakteru, wyjątkowa osobowość kształtowały umysły i serca księży pokolenia międzywojennego oraz stanowiły wzór dla kapłanów XX wieku ${ }^{83}$. W konsekwencji skutkiem odnowy życia liturgicznego była także odnowa kaznodziejstwa ${ }^{84}$. Okazały dorobek naukowo-publicystyczny ${ }^{85}$ był powodem wdzięczności diecezji chełmińskiej wobec ks. Bieszka ${ }^{86}$. Prace te są nadal aktualne, można korzystać z jego dorobku, poprzez, który na wiele lat wyprzedził to, co przekazał nam Drugi Sobór Watykański ${ }^{87}$.

78 Zob. Pius XII, Encyklika „Mediator Dei”, Kielce 1948, s. 49; D. Brzeziński, Teologiczne rozumienie liturgii. W 50 rocznica ogłoszenia encykliki Piusa XII ,, Mediator Dei”, dz. cyt., s. 120.

79 Zob. B. Kosecki, dz. cyt., s. 179-180.

80 Zob. tamże, s. 177.

81 Zob. S. Człapa, Ks. dr Kazimierz Bieszk-Prekursor Odnowy Liturgii i Wychowawca, dz. cyt., s. $77-78$.

82 Zob. J. Walkusz, dz. cyt., s. 131.

83 Zob. H. Jastak, dz. cyt., s. 20, 122; J. Walkusz, dz. cyt., s. 131, 134.

84 Zob. ttamże, s. 376.

85 Zob. A. Liedtke, Tradycje Naukowe Pelplina, dz. cyt., s. 21.

${ }_{86}$ Zob. J. Walkusz, dz. cyt., s. 374.

87 Zob. tamże, s. 376. 


\section{Bibliografia}

Benedykt XVI, Adhortacja apostolska ,Sacramentum Caritatis”, Rzym 2007.

Benedykt XVI, Adhortacja apostolska ,,Verbum Domini”, Rzym 2010.

Bieszk K., Kazania o Eucharystii, „Przegląd Homiletyczny”, 1935, t. XIII.

Bieszk K., Ofiara Nowego Przymierza, Pelplin 1937.

Bieszk K., Co sądza świeccy o kazaniu, „Miesięcznik Diecezji Chełmińskiej”, 1933.

Bieszk K., Liturgia jako źródło kazań, Kielce 1935.

Bieszk K., Liturgia, „Homiletyka Duszpasterska”, 1935.

Blachnicki F., Konieczność odnowy liturgii na tle jej tradycyjnej koncepcji, w: Wprowadzenie do liturgii, red. F. Blachnicki, W. Schenk, R. Zielasko, Poznań 1967.

Broński W., Homilia w dokumentach Kościoła współczesnego, „Studia Homiletyczne Katedry Homiletyki KUL”, 1999.

Broński W., Homilia w nauczaniu Kościoła wspótczesnego, „Studia Teologiczno-Filozoficzne Diecezji Rzeszowskiej”, t. 5(1998).

Brzeziński D., Teologiczne rozumienie liturgii. W50 rocznica ogłoszenia encykliki Piusa XII „,Mediator Dei”, „Miesięcznik Pasterski Płocki” 82(1997).

Brzeziński D., Ukształtowanie i wyposażenie wnętrza kościoła w odnowionym rycie rzymskim: aspekt liturgiczno-prawny, „Studia Płockie”, 29(2001).

Człapa S., Kazimierz Bieszk, EK 2.

Człapa S., Ks. dr Kazimierz Bieszk-Prekursor Odnowy Liturgii i Wychowawca, „Studia Pelplińskie”, 15(1984).

Człapa S., Ks. Kazimierz Bieszk jako Liturgista, „Studia Pelplińskie”, 1978

Dyk S., Homilia - droga do żywego poznania Misterium Chrystusa, Kielce 2016.

Jastak H., Dorobek homiletyczny Ks. Prałata Dr Kazimierza Bieszka, Pelplin.

Konferencja Episkopatu Polski, Wskazania Konferencji Episkopatu Polski dotyczace homilii mszalnej, Lublin 2017.

Kosecki B., Znajomość historii liturgii warunkiem skutecznej Odnowy Liturgicznej, „Studia Pelplińskie”, 11(1980).

Krakowiak Cz., Eucharystia w parafii. Teologia i praktyka pastoralna, Lublin 2014.

Liedtke A., Straty teologiczne nauki polskiej podczas wojny, „Ateneum Kapłańskie", t. 47(1947).

Liedtke A., Tradycje Naukowe Pelplina, „Studia Pelplińskie”, 1969.

Manthey F., Ks. Kazimierz Bieszk, w: J. Borzyszkowski, Pro Memoria, Stefan Bieszk (1895-1964), Gdańsk 2013. 
Manthey F., Ks. Kazimierz Bieszk, w: J. Walkusz, Duchowieństwo katolickie diecezji chetmińskiej w latach 1918- 939, Pelplin 1992.

Marini P., Liturgia i piękno Nobilis Pulchritudo, Pelplin 2017.

Megger A., Studia Pelplińskie w stużbie liturgii, „Studia Pelplińskie”, t. 50(2017).

Milcarek P., Historia Mszy, Kraków 2009.

Mross H., Bieszk Kazimierz (1890-1946), homiletyk, liturgista, redaktor, w: Słownik Polskich Teologów Katolickich 1918-1981, red. L. Grzebień, Warszawa 1983.

Nadolny A, Pelpliński Krag Historyczny, w: Dzieje Historiografii Pomorza Gdańskiego i Prus Wschodnich 1920-1939 (1944), red. A. Tomczak, Toruń 1991.

Panuś K., Sztuka Gtoszenia Kazań, Kraków 2008.

Pius XII, Encyklika „Mediator Dei”, Kielce 1948.

Przyczyna W., Z zagadnień współczesnej homiletyki, Kraków 1993.

Rutkowski A., Liturgia zanurzeniem w Boża obecność, „Studia Pelplińskie”, t. 36( 2005).

Sicari A. M., Eucharystia-Ofiara Chrystusa, Kościoła i Ludzkości, w: Eucharystia, red. S. Stencel, Poznań 1986.

Sicari A. M., Życie duchowe chrześcijanina, thum. M. Brzezinka, t. XVII.

Sławiński H., Tematyczne Programowanie Przepowiadania Homilijnego, „Roczniki Teologiczne”, t. 62(2015).

Sławiński H., Znaczenie, geneza i struktura Dyrektorium Homiletycznego, „Polonia Sacra” 3(2015).

Szulist W., Przeszłość obecnych obszarów diecezji pelplińskiej 1929-1939. Tom 3, Pelplin 2009.

Walkusz J., Duchowieństwo katolickie diecezji chełmińskiej w latach 1918 1939, Pelplin 1992.

Wielgoszewski W., Pedagog, który zbliżat do Boga. Duchowni diecezji chetmińskiej (9A), „Niedziela”, 23(2007).

Wronka A., Liturgia na ambonie. Zasady i wskazówki, Poznań 1933.

Zachara M., Msza Święta, Warszawa 2014.

Zadura R., Błogostawiony ks. Stefan Frelichowski (1913-1945). Biografia, Toruń 2006. 